\title{
Evaluation of pollen fertility in pepino (Solanum muricatum Ait.)
}

\author{
Katarzyna Kowalczyk ${ }^{1}$, Jolanta Kobryn' ${ }^{1}$, Wojciech Zieliński ${ }^{2}$ \\ ${ }^{1}$ Department of Vegetable and Medicinal Plants \\ ${ }^{2}$ Department of Computer Sciences \\ Warsaw University of Life Sciences \\ Nowoursynowska 159, 02-776 Warsaw, Poland \\ e-mail: k_kowalczyk@sggw.pl
}

Key words: clone, cultivation time, rockwool, peat

\begin{abstract}
The influence of the cultivation time (spring-summer and autumn) and the kind of cultivation (on rockwool and peat) on the fertility of pollen coming from three successive trusses were studied for six different pepino clones. The fertility was defined in vitro as the capacity of pollen for germinating. The average capacity of pollen germination ranged in the studied clones from 10 to $15 \%$. These clones displayed the highest pollen fertility in an autumn cultivation, comparing to a spring-summer one. Higher rate of pollen fertility was observed during a springsummer cultivation on first trusses in most of the clones studied. The pollen of all plants grown on rockwool was more fertile, comparing to the cultivation on peat substrate. High differences in pollen fertility of the clones were obtained.
\end{abstract}




\section{INTRODUCTION}

According to Proctor et al. (1994), pepino (Solanum muricatum Aiton) focuses research in many countries owing to a permanently increasing customers' interest in new exotic plants and fruit. Pepino fruit are appreciated for their specific taste, recalling delicate and sweet melons, its aroma, as well as high content of vitamin C and mineral salts (Redgewell and Turner 1986, Shiota et al. 1988, Ahumada and Cantwell 1996, Anderson et al. 1996). In America and other regions where pepino is grown, high diversity within the species occurs. The plant is characterized by unevenness of fruit setting and yielding (Murray et al. 1992). According to Burge (1989) and Ruiz et al. (1996) the cause of an unsatisfactory fruit setting in pepino is poor pollen release and its bad fertility. Therefore, already in 1995, FernandezMunoz et al. conducted the selection of their clones for efficacy of pollination and fertilization processes, under unfavorable cultivation conditions.

The aim of the study was the evaluation of pollen fertility in pepino grown under glasshouse conditions, in relation to a technique and time of production.

\section{MATERIAL AND METHODS}

In 1999 and 2000, the influence of the cultivation cycles: spring-summer (plants were planted on March 20 and the experiment ended on July 15 each year) and autumn (on July 20 and on November 15, respectively) and the type of substrate (rockwool and peat) on the fertility of pollen coming from three consecutive trusses were studied for six different pepino clones. Clones from New Zeland were marked 1 to 5 , a clone from Israel was numbered 6 . The fertility was defined in vitro as the capacity of pollen for germinating. For this purpose, tree factorial experiment was set in eight replications, one plot with 5 plants, in randomized blocks design. A cultivation time was the first factor, a type of substrate the second one, while a kind of pepino clone the third one. Plants were prepared from softwood cuttings and then grown in a glasshouse on rockwool Flormin or peat substrate. The nutrient solution for the plants growing on rockwool was in the following content of macro- and microelements in $\mathrm{mg} \mathrm{L}^{-1}: \mathrm{N}-140, \mathrm{P}-70, \mathrm{~K}-350, \mathrm{Mg}-60, \mathrm{Ca}-$ $190, \mathrm{Fe}-2.0, \mathrm{Mn}-0.6, \mathrm{Cu}-0.2, \mathrm{Zn}-0.3, \mathrm{~B}-0.3$, and $\mathrm{Mo}-0.2$. The contents of macro- and microelements in $\mathrm{mg} \mathrm{L}^{-1}$ of peat substrate were as follows: $\mathrm{N}-250, \mathrm{P}-$ $200, \mathrm{~K}-500, \mathrm{Mg}-160, \mathrm{Fe}-10, \mathrm{Mn}-3, \mathrm{Cu}-12, \mathrm{Zn}-1, \mathrm{~B}-3, \mathrm{Mo}-1$ and $\mathrm{pH}$ 6.0-6.5. Plants were grown in accordance to cultivation recommendations for tomato. They were planted at 5 plants per $\mathrm{m}^{2}$ and grown for a single stem and three trusses. During the blossoming of the consecutive trusses, two flowers from each plant were collected. After two days, another two flowers were collected. For each clone and combination, pollen fertility of 12 flowers was estimated. The pollen 
from these flowers was then grown on the medium which in the earlier study of Kowalczyk et al. (2001) had given the best results for germinating of pepino pollen. The composition of that medium was as follows:

$\begin{array}{ll}\mathrm{Ca}\left(\mathrm{NO}_{3}\right)_{2} \times 4 \mathrm{H}_{2} \mathrm{O} & 300 \mathrm{ppm} \\ \mathrm{MgSO}_{4} \times 7 \mathrm{H}_{2} \mathrm{O} & 200 \mathrm{ppm} \\ \mathrm{KNO}_{3} & 100 \mathrm{ppm} \\ \mathrm{H}_{3} \mathrm{BO}_{3} & 200 \mathrm{ppm} \\ \text { Sucrose } & 2 \% \\ \text { Agar Agar Serva Kobe I } & 4.5 \mathrm{~g} \mathrm{dm}^{-3} \\ \text { pH } & 5.8\end{array}$

The capacity of pepino pollen for germinating was estimated 24 hours after it was sown. Using a light microscope $(200 \times$ magnification), all pollen grains and germinating pollen were counted from 10 visual fields randomly selected from each sample. A percentage of germinating pollen grains was calculated and interpreted as the capacity of pollen for germinating. The results obtained were categorized in three groups:

- $\quad$ GROUP 0 - sterile pollen (germination capacity ranged from 0 to $1 \%$ );

- GROUP 1 - pollen of a poor germination capacity (germination capacity ranged from 1 to $10 \%$ );

- $\quad$ GROUP 2 - pollen of a moderate germination capacity (germination capacity equaled and exceeded $10 \%)$.

The test of chi-square independence (Cochran 1977) was many times applied for the purpose of checking the existence of differences between the studied factors, i.e.: cultivation cycles, type of substrate, number of consecutive truss and clone of pepino. For each figure the p-value of the chi-square test was attached.

\section{RESULTS}

Pollen of the clones studied had a low fertility ratio. The highest value of germination capacity did not exceed 30\%. Most flowers qualified for group 2 of moderate fertile pollen gave results ranging from 10 to $15 \%$. For most of the clones cultivated in autumn, higher fertility of pollen was observed, comparing to a spring-summer cultivation (Fig. 1). However, some differences in pollen fertility between the clones marked in these cultivation dates. Clones 1, 3, 4 and 6 reacted by increasing the number of the flowers with moderate-fertile pollen, in relation to a spring-summer cultivation. Clones 2 and 5, however, had the highest frequency of sterile pollen, in both dates of cultivation (Fig. 1). 
In a spring-summer seasons, clone 1 had the highest pollen fertility, comparing to other clones, showing the highest number of flowers with the ratio of pollen germination capacity matching group 2 . In this date of cultivation, also clones 3 and 6 had many flowers with fertile pollen. In autumn, best results in this respect gave clones 6, 1, 3 and 4, listed in decreasing order (Fig. 1).

Pollen of higher fertility was produced by the plants grown on rockwool than on peat substrate, irrespectively whether of the spring-summer or an autumn cultivation (Figs 2 and 3). In clones 1, 3 and 4, pollen of a lesser fertility was observed for the cultivation on peat substrate, both in the spring-summer and autumn seasons. However, the fertility of pollen in clone 6 was lower for the cultivation on peat in the spring-summer season, while in the autumn season, the pollen fertility for plants grown on both types of substrate was similar (Fig. 3).

On consecutive trusses, germination capacity of pollen from the clones studied was different irrespectively of the cultivation season (Fig. 4). Slightly higher pollen fertility was stated for the first trusses of clones 1, 3 and 6 . However, the highest frequency of sterile pollen was observed for clones 2 and 5, irrespectively of the consecutive truss (Fig. 4). Despite this, fertile pollen was observed in flowers on all trusses of clone 2 only in spring 2000 (Figs 5, 6, 7 and 8). Pollen of clones 3 and 6 coming from the spring-summer cultivation of 1999 and 2000, and collected from flowers of first trusses was more fertile than pollen coming from another two, consecutive trusses, except foe the results for clone 3 on second truss in 2000 (Figs 5 and 7). On the other hand, pollen fertility of these clones in the autumn cultivation was higher on trusses 2 and 3, comparing to truss 1 (Figs 6 and 8). In autumn 1999, clone 6 had the most fertile pollen in flowers of 2 and 3 truss, comparing to the other clones of the same cultivation date as well as to consecutive trusses (Fig. 6). Pollen fertility of clone 4 from trusses 2 and 3, however, was similar to this of clone 3 recorded in the same season, while in spring, was the highest frequency of sterile pollen of the former on all three trusses (Figs 5 and 6).

In spring 2000, clones 1 and 6 showed the highest pollen fertility on first trusses whereas on consecutive trusses, a decrease in fertility was observed which was particularly visible for clone 6 (Fig. 7). In an autumn cultivation of this year, an increase of fertility was observed on the third truss for clones 1,4 and 6 and on all trusses for clone 3 , in relation to the corresponding results obtained in a spring date (Figs 7 and 8).

Comparing the percentage share of observations categorized in 0,1,2 groups of germination capacity (Fig. 9), the highest fraction of flowers with pollen of a moderate germination capacity yielded plants of clone 1 . In the clone 6 , over $50 \%$ of flowers had pollen and also qualified for the group 2, and $20 \%$ flowers with group 1 . Clone 1 produced the highest fertility pollen. In clone 3 , over $30 \%$ of flowers observed had sterile pollen, over $50 \%$ had moderately fertile and the pollen 
of over $10 \%$ flowers displayed poor fertility. Almost $50 \%$ of the flowers of clone 4 , and over $90 \%$ of the flowers of clones 2 and 5 had sterile pollen (Fig. 9).
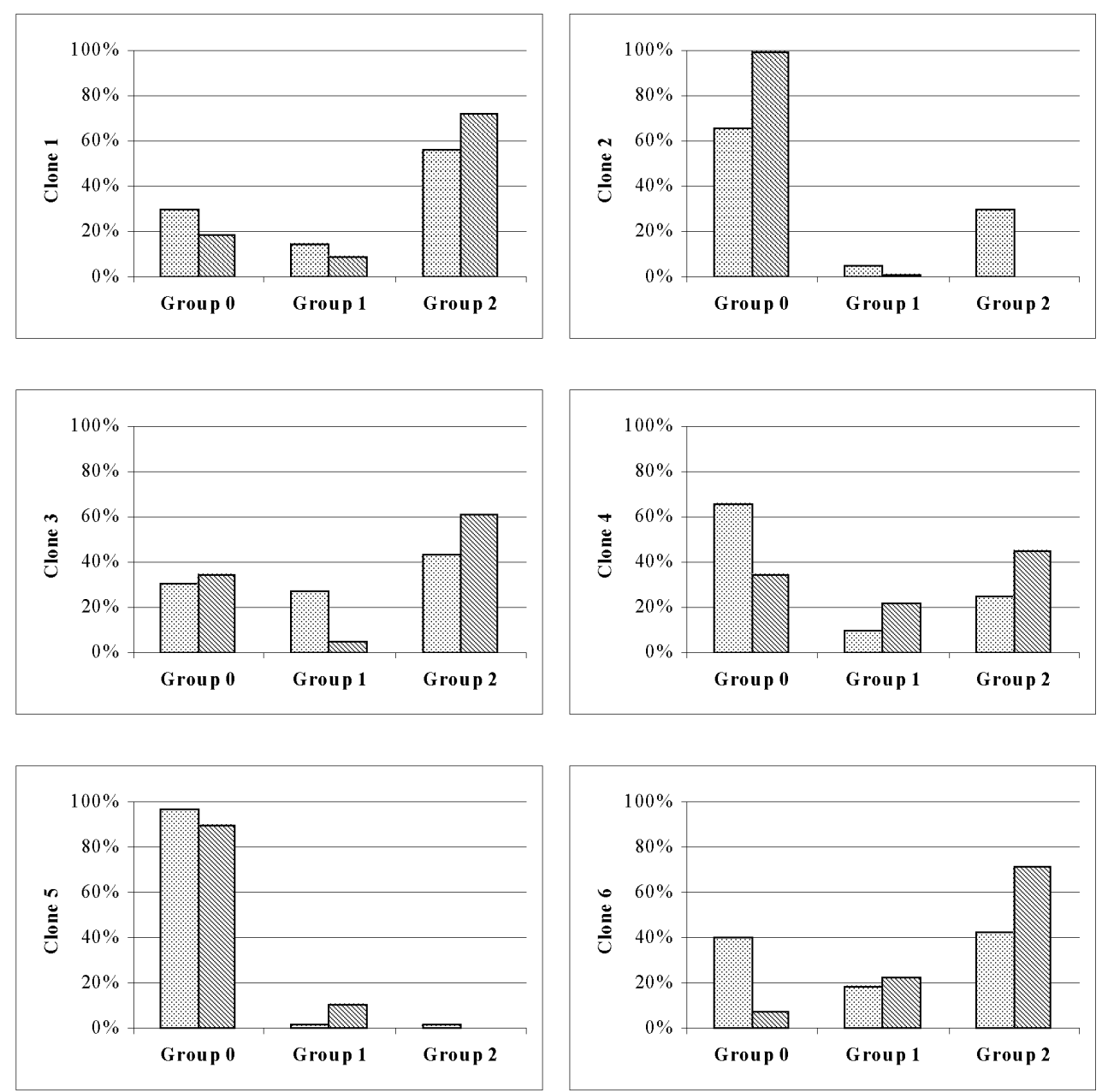

Spring-summer

$\mathbb{\mathbb { N }}$ Autumn

Fig. 1. Ability of pollen germination (Group 0 - non-germinating pollen, Group 1 - pollen of a poor germination capacity, and Group 2 - pollen of moderate germination capacity) of six pepino clones in dependence on the growing season (means from 2 years) $p<0.00005$ 

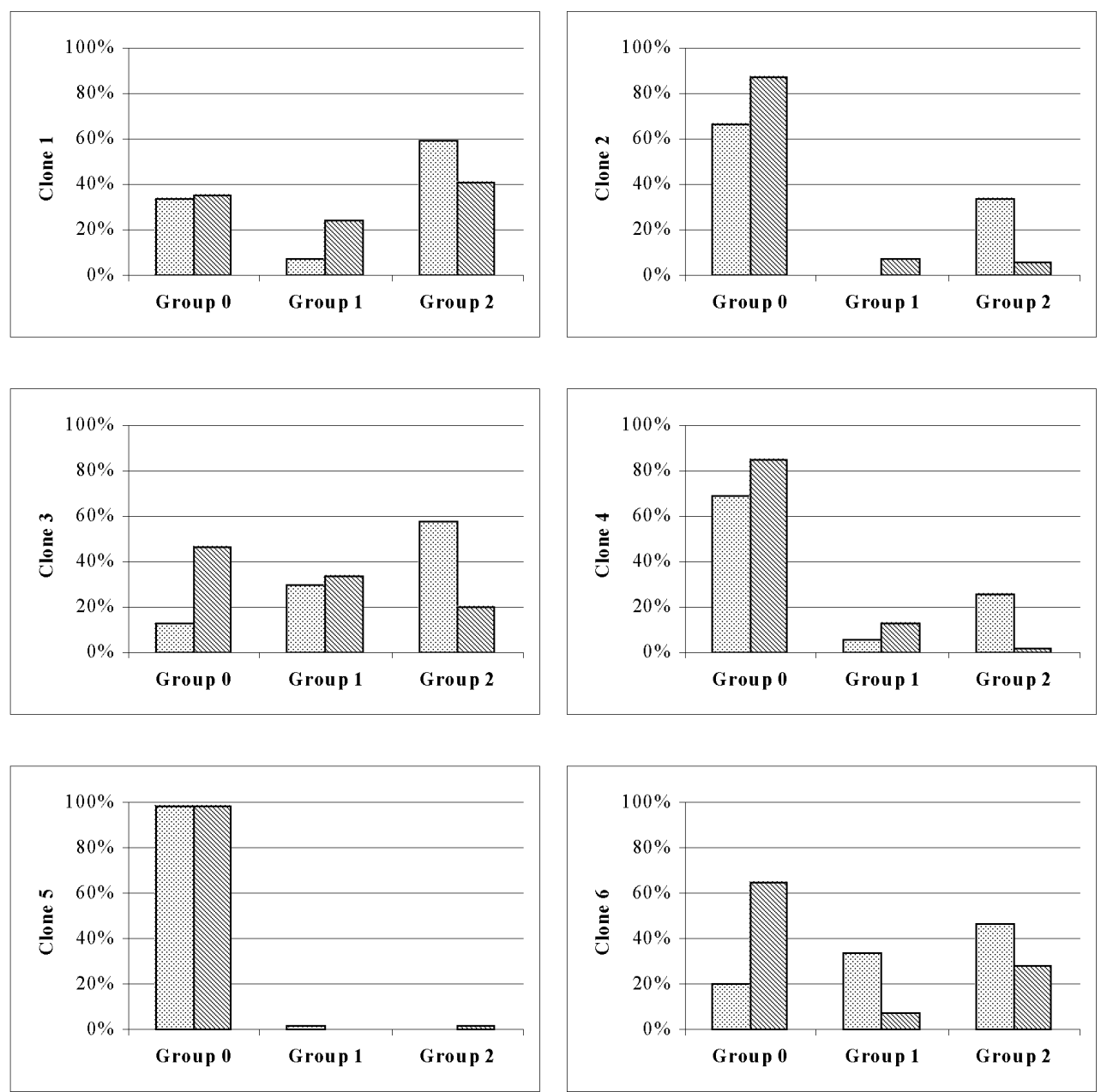

Rockwool

$\mathbb{Q}$ Peat

Fig. 2. Ability of pollen germination (Group 0 - non-germinating pollen, Group 1 - pollen of a poor germination capacity, and Group 2 - pollen of moderate germination capacity) of six pepino clones in dependence on the kind of substrate in spring-summer (means from 2 years) $p<0.00005$ 

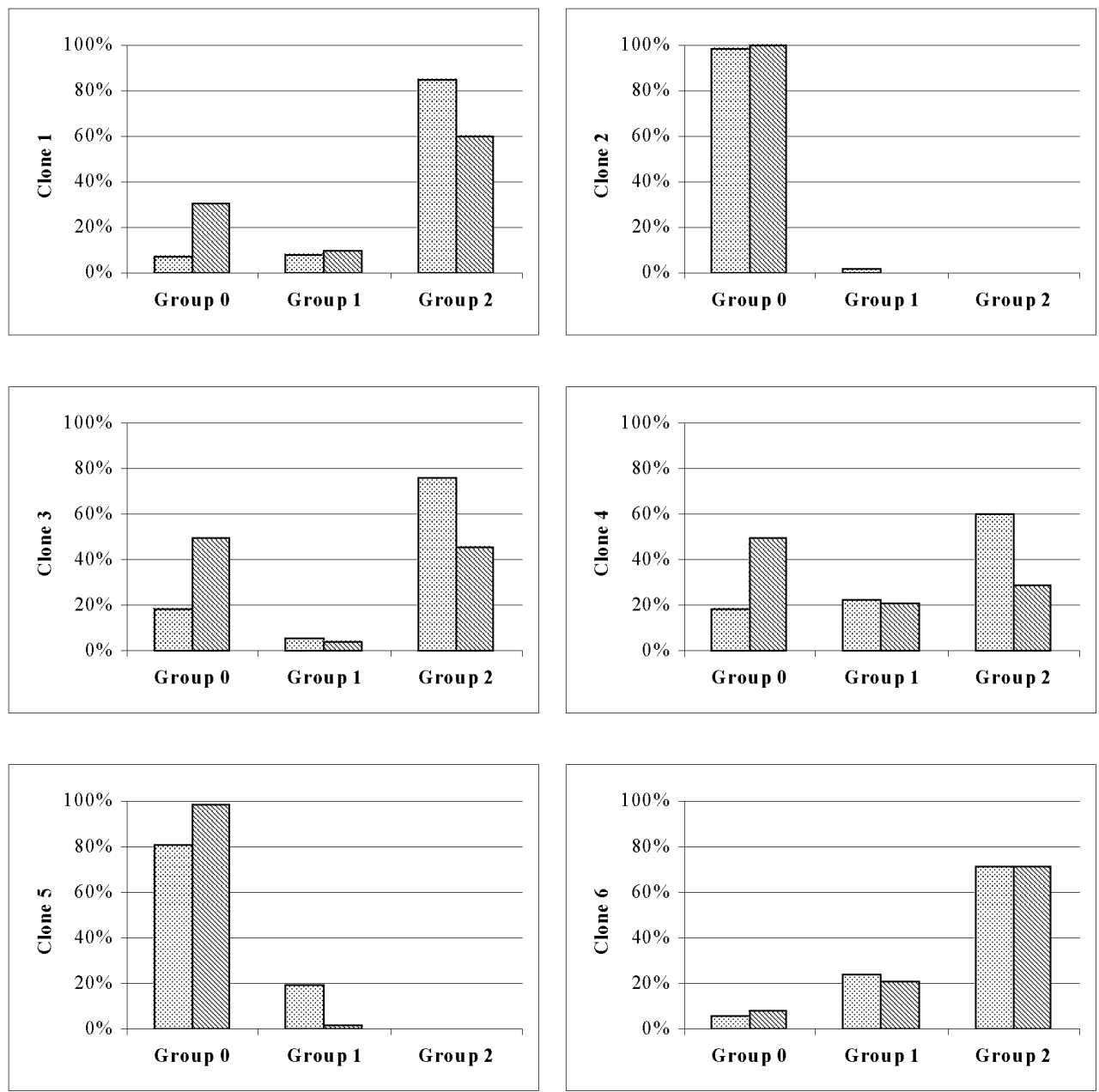

Rockwool

$\mathbb{Q}$ Peat

Fig. 3. Ability of pollen germination (Group 0 - non-germinating pollen, Group 1 - pollen of a poor germination capacity, and Group 2 - pollen of moderate germination capacity) of six pepino clones in dependence on the kind of substrate in autumn (means from 2 years) $p<0.00005$ 

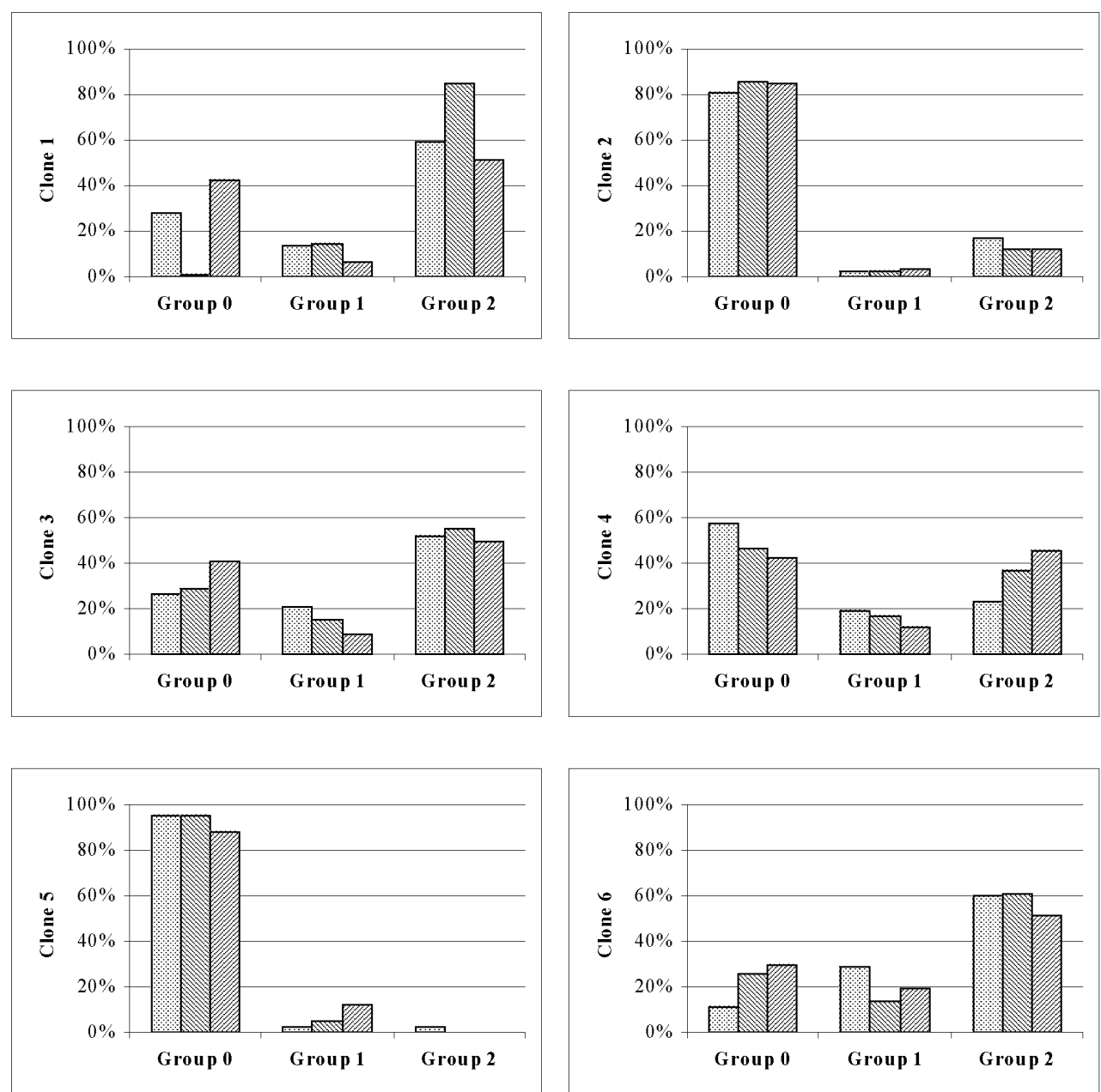

Truss I $\mathbb{Q}$ Truss II 娄 Truss III

Fig. 4. Ability of pollen germination (Group 0 - non-germinating pollen, Group 1 - pollen of a poor germination capacity, and Group 2 - pollen of moderate germination capacity) of pepino on successive trusses (means from substrates, growing seasons and 2 years) $p<0.00005$ 

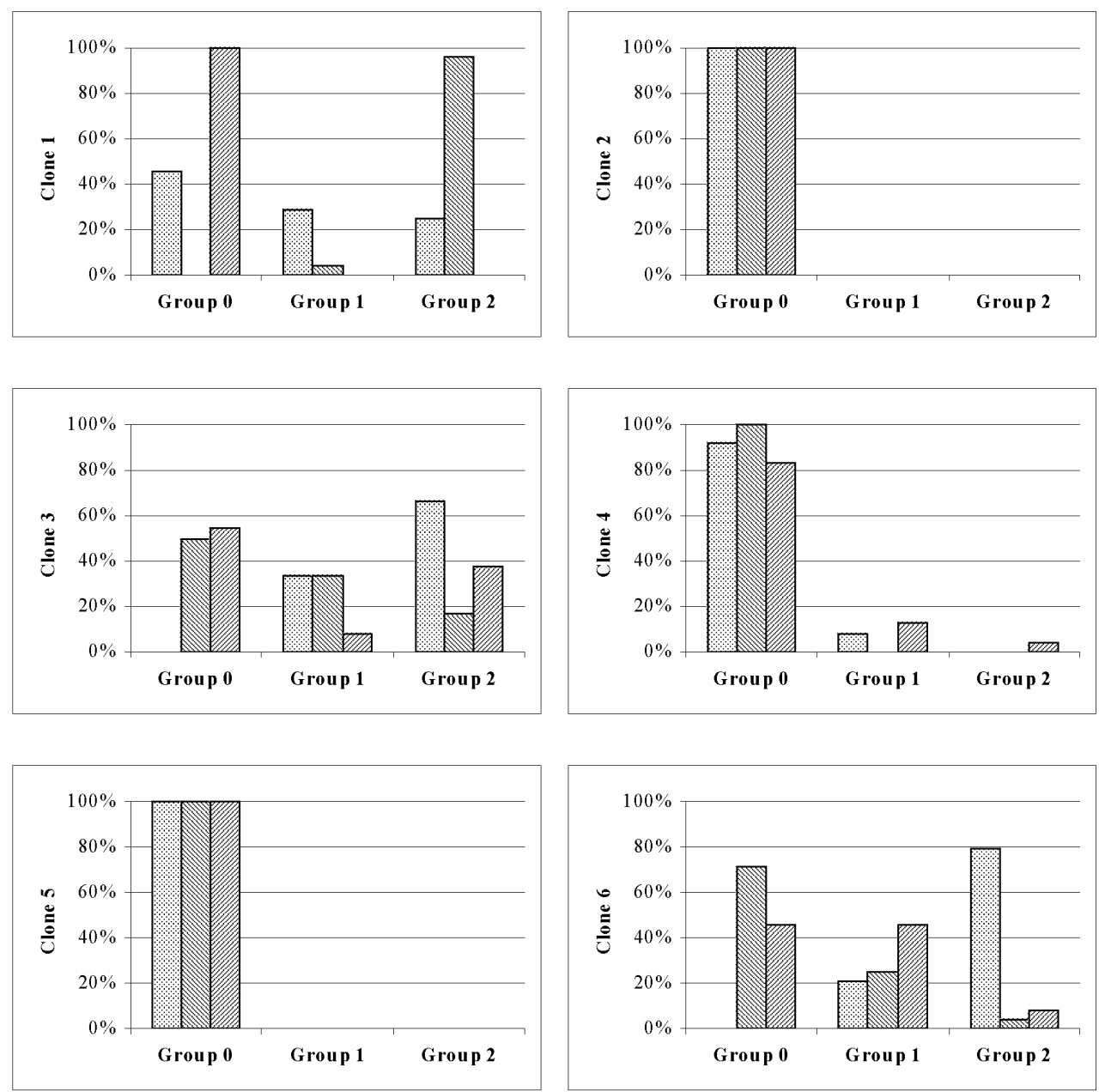

Truss I Truss II 圆 Truss III

Fig. 5. Ability of pollen germination (Group 0 - non-germinating pollen, Group 1 - pollen of a poor germination capacity, and Group 2 - pollen of moderate germination capacity) of pepino on successive trusses in spring-summer (means from substrates in 1999 year) $p<0.00005$ 

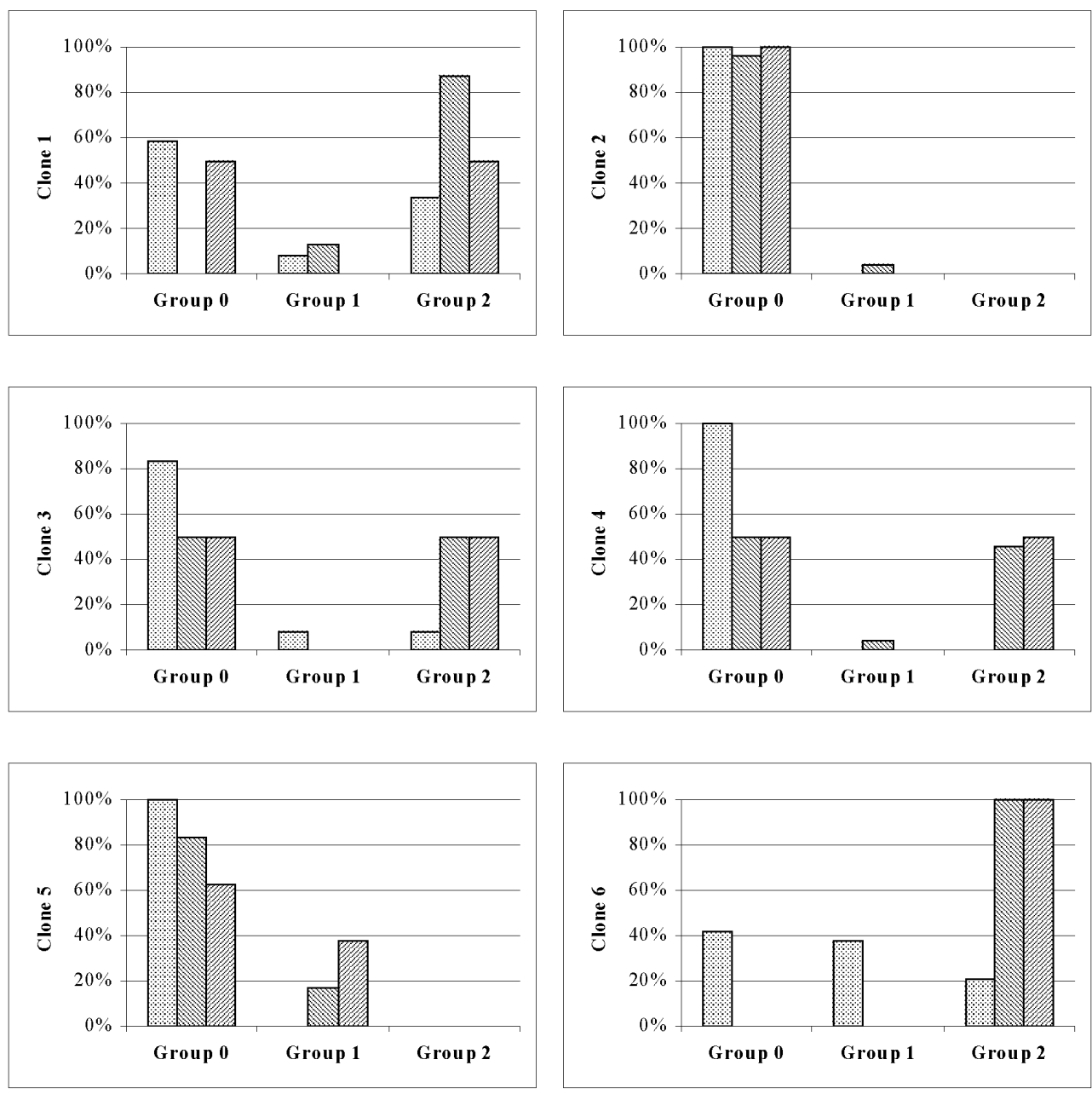

Truss I Truss II 圈 Truss III

Fig. 6. Ability of pollen germination (Group 0 - non-germinating pollen, Group 1 - pollen of a poor germination capacity, and Group 2 - pollen of moderate germination capacity) of pepino on successive trusses in autumn (means from substrates in 1999 year) $p<0.00005$ 

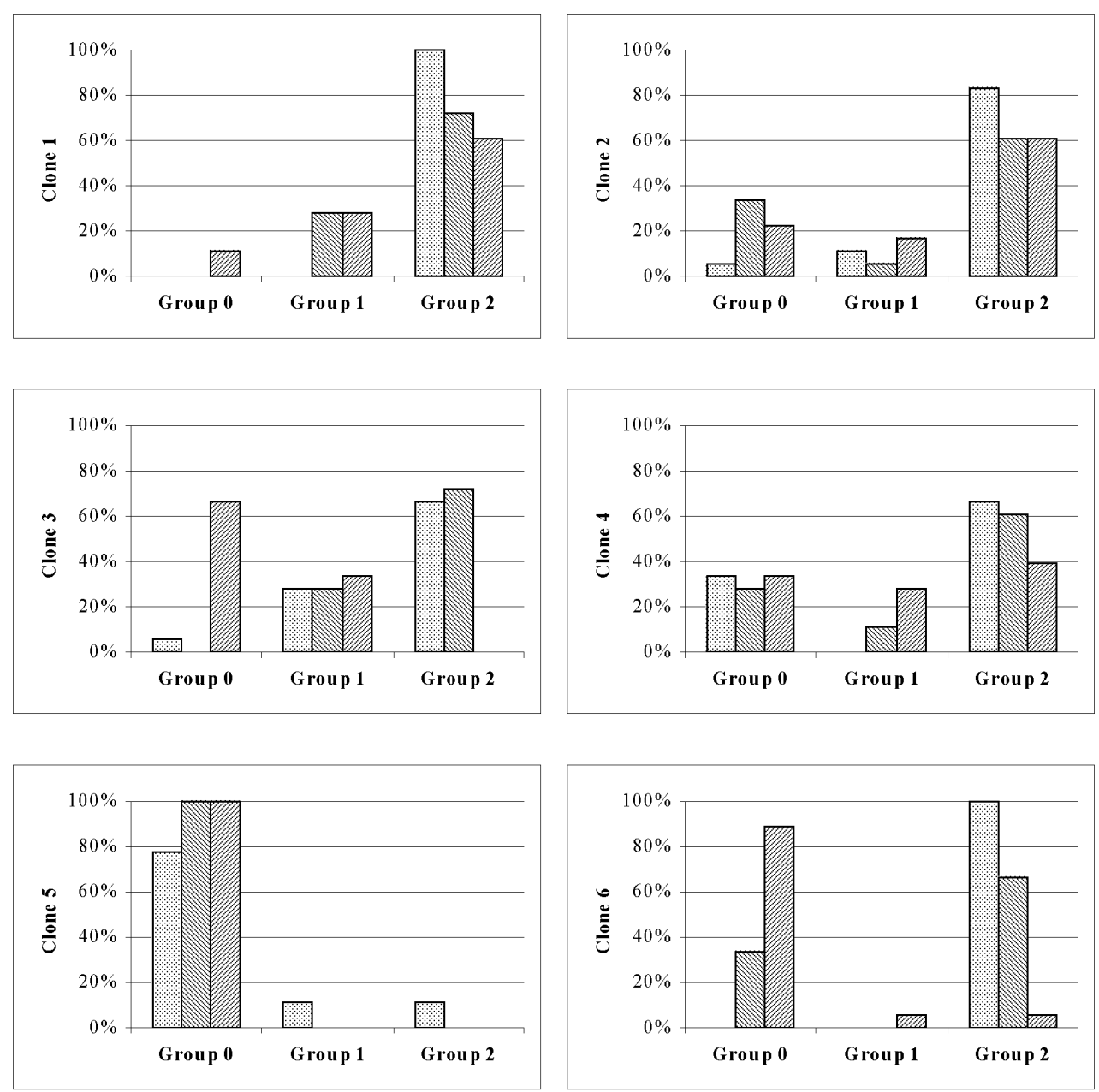

Truss I $\mathbb{Q}$ Truss II 曾 Truss III

Fig. 7. Ability of pollen germination (Group 0 - non-germinating pollen, Group 1 - pollen of a poor germination capacity, and Group 2 - pollen of moderate germination capacity) of pepino on successive trusses in spring-summer (means from substrates in 2000 year) $p<0.00005$ 

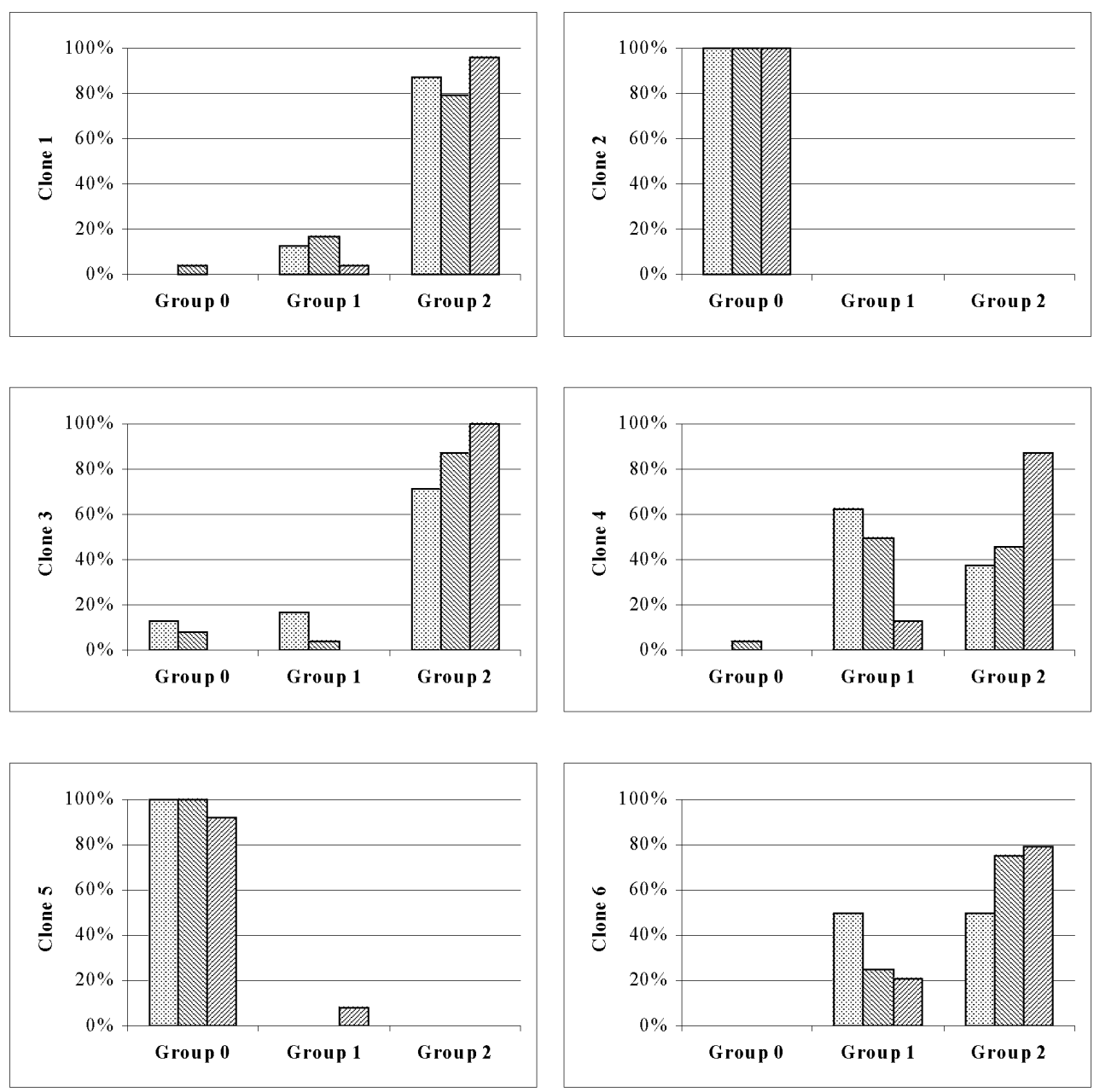

Truss I Truss II 罥 Truss III

Fig. 8. Ability of pollen germination (Group 0 - non-germinating pollen, Group 1 - pollen of a poor germination capacity, and Group 2 - pollen of moderate germination capacity) of pepino on successive trusses in autumn (means from substrates in 2000 year), $p<0.00005$ 


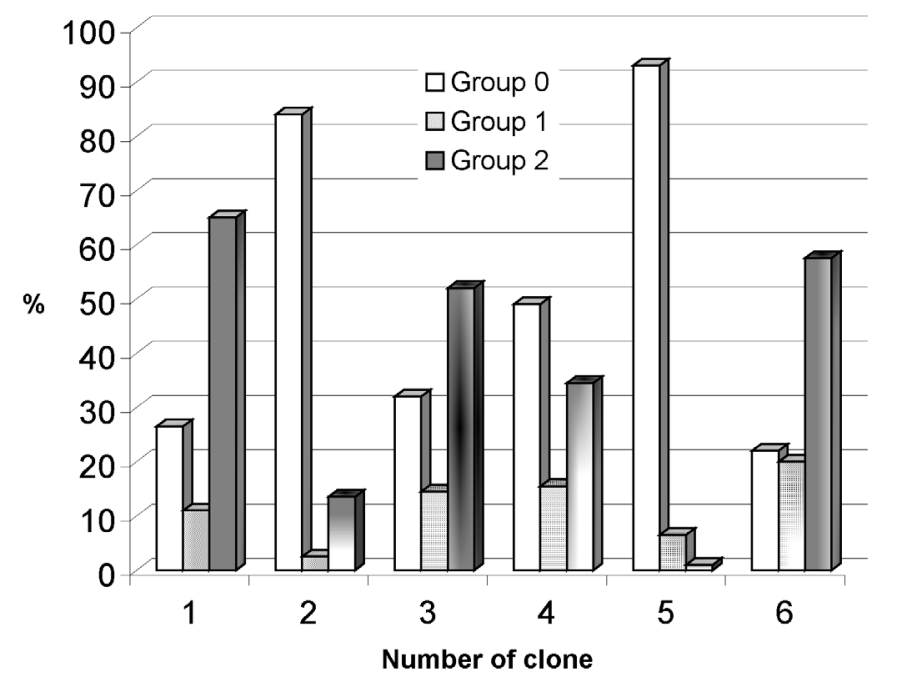

Fig. 9. Ability of pollen germination (Group 0 - non-germinating pollen, Group 1 - pollen of a poor germination capacity, and Group 2 - pollen of moderate germination capacity) of pepino in dependence on the clone (means from 2 years) $p<0.00005$

\section{DISSCUSSION}

Pollen fertility was very variable and depended on many environmental factors but primary on temperature, which when exceeding $30^{\circ} \mathrm{C}$, can lead to its deterioration (Grigg et al. 1988, Ercan and Akilli 1996, Ruiz et al. 1996). At investigating pollen fertility in vitro, a similar situation occurred in all the clones, irrespectively of the cultivation season. Despite the fact that the methods of assessing pollen fertility in vitro are less reliable (they verify only one of its aspects), germinating of fresh pollen on a medium, acknowledged to express pollen capacity for germinating, is most frequently applied (El Ahmadi and Stevens 1979). According to Ruebenauer and Muller (1985), pollen grains germinating on artificial media can be considered vital.

The clones of pepino studied in the present work, displayed the highest pollen fertility in an autumn cultivation, comparing to a spring-summer cultivation. It could have resulted both from temperature and light conditions.

Moss and Heslop-Harrison (1968), Charles and Harris (1972), Kinet et al. (1978), Rylski and Spiegelman (1982), Saini and Aspinall (1982) claim different environmental factors such as temperature, substrate humidity and light intensity, responsible for pollen fertility. 
Differences in pollen fertility rate of consecutive trusses observed also in the clones studied could be influenced by temperatures before and at the blossoming of the plants, particularly high in a spring-summer cultivation.

Higher pollen fertility observed during the spring-summer cultivation on the first trusses in most of the clones studied could have resulted from a lower temperature recorded at that time. Although in the autumn, cultivation an overall temperature had been lower, no such relations were noted. Studies of Kowalczyk and coworkers (2001) revealed a strong correlation in some pepino clones between pollen fertility and glasshouse temperatures, measured during a two-week period of pollen grains' development. Substrates used in the experiment also had some impact on pollen fertility. The pollen of all plants grown on rockwool was more fertile, comparing to the cultivation on peat substrate. Such differences presumably resulted from different fertilization requirements, higher in the case of tomato culture on peat substrate.

The average germination capacity of pepino pollen ranged from 10 to $15 \%$, corroborating its low fertility. Ercan and Akilli (1996) have also observed a low ratio of pollen fertility in pepino, ranged from 7.53 to $8.00 \%$. Burge (1989), on the other hand, determined pollen fertility in vitro for several pepino varieties at the level of $70 \%$ for glasshouse production and $56 \%$ for field production. Such significant differences in pollen fertility reported by the authors could have been a result of conducting the studies on different clones. Another reason could be using the method to estimate pollen fertility. For example, the results on pollen vitality obtained with the use of acetocarmine staining were considerably higher. However, this method of evaluating pollen fertility has been criticized for giving the results different from its actual vitality (Ruebenbauer and Muller 1985).

According to Prohens et al. (1996), pollen fertility in pepino not only depends on environmental conditions of their growth but also on a clone or a variety. Similarly, in the present work, high differences in pollen fertility of the clones compared were obtained. For clones 2 and 5 sterile pollen was stated even in $80-90 \%$ of flowers, whereas clones 1 and 6 produced only $20-25 \%$, clone $3-30 \%$ and clone 4 up to $50 \%$ of flowers with no vital pollen. The highest number of flowers with vital pollen, displaying an above $10 \%$ germination capacity, was observed in plants of clone 6 and then in the decreasing order followed clone 1, 3 and 4 . Both, in the tests on pollen germinating on stigma as well as in in vitro studies, pollen of clone 1 appeared slightly less susceptible to high temperature in comparison to the other clones (Kowalczyk et al. 2001, Kopcińska at al. 2002 a and b).

Despite the lack of pollination barriers and the intrinsic pollen fertility, the clones compared display a strong tendency to set parthenocarpic fruit (Kowalczyk not public). Facultative parthenocarpy occurs in tomato and other species in which the mechanisms of pollination and fertilization are strongly determined by precise environmental conditions (Georg et al. 1984). 
The use of parthenocarpic pepino clones (not requiring pollination for fruit setting) in crop can enable obtaining high yield despite conditions adverse for fruit formation (Prohens et al. 1998). Owing to uneven production rate of seeded fruit which in term give progeny of variable yield, a vegetative method of propagation prevails in pepino as it provides both fruit quality and quantity (Pluda et al. 1993).

\section{CONCLUSIONS}

- The average capacity of pollen germination ranged in the studied clones from 10 to $15 \%$, corroborating its low fertility.

- The clones of pepino studied in the present work, displayed the highest pollen fertility in the autumn cultivation, comparing to the spring-summer cultivation.

- Higher rate of pollen fertility observed during the spring-summer cultivation on first trusses in most of the clones.

- The pollen of all plants grown on rockwool was more fertile, comparing to the cultivation on peat substrate.

- High differences in pollen fertility of the clones compared were obtained.

\section{REFERENCES}

Ahumada M., CANTwell M., 1996. Postharvest studies on pepino dulce (Solanum muricatum Ait.): Maturity at harvest and storage behavior. Postharvest Biol. Technol. 7: 129-136.

ANDERSON G.J., JANSEN R.K., KIM Y., 1996. The origin and relationships of the pepino, Solanum muricatum (Solanaceae): DNA restriction fragment evidence. Econ. Bot. 50(4): 369-380.

BURGE G.K., 1989. Fruit set in the pepino (Solanum muricatum Ait.). Sci. Hort. 41: 63-68.

ChARlES W.B., HARRIS R.E., 1972. Tomato fruit-set at high and low temperatures. Can. J. Plant Sci. 52: 497-506.

Cochran W.G., 1977. Sampling Techniques. $3^{\text {rd }}$ Ed., Wiley Eastern Limited, New Delhi.

El AHMADi A.B., STEVens M.A., 1979. Reproductive responses of heat-tolerant tomatoes to high temperatures. J. Am. Soc. Hortic. Sci. 104 (5): 686-691. 
ERCAN N., AKILLI M., 1996. Reasons for parthenocarpy and the effects of various hormone treatments on fruit set in pepino (Solanum muricatum Ait.) Sci. Hortic. 66: 141-147.

FERNANDEZ-MUNOZ R., GONZALEZ-FernANDEZ J.J., CUARTERO J., 1995. Genetics of the viability of pollen grain produced at low temperatures in Lycopersicon Mill. Euphyt. 84: 139-144.

GeORG W.L., SCOTt J.W., SPlittstoesSeR W.E., 1984. Parthenocarpy in tomato. Hort. Rev. 6: 65-84.

Grigg F.D.W., SMith P.R., Stenersen M.A., MurRay B.G., 1988.Variable pollen fertility and abnormal chromosome behavior in the pepino (Solanum muricatum Ait., Solanaceae). Sci. Hort. 35: 259-268.

Kinet J.M., Hurdebise D., Parmentier A., Stainier R., 1978. Promotion of inflorescence development by growth substance treatments to tomato plants grown in insufficient light conditions. J. Am. Soc. Hortic. Sci. 103: 724-729.

KoPCIŃSKA J., ŁOTOCKA B., KOWALCZYK K., KOBRYŃ J., 2002 a. Flower organs of Solanum muricatum Aiton. I. Perianth and stamen. Acta Biol. Cracov., Ser. Bot. 44: 125-134.

KOPCIŃSKA J., ŁOTOCKA B., KOWALCZYK K., KOBRYŃ J., 2002 b. Flower organs of Solanum muricatum Aiton. II. Pistil. Acta Biol. Cracov., Ser. Bot. 44: 135-143.

KowalczyK K., KobryŃ J., RaKoczy TROJANOWSKa M., 2001. Comparison of pollen fertility of some pepino clones (Solanum muricatum Aiton) in different growing periods. Folia Hort. 13/1A: 309-314.

Moss G.I., HESLOP-HARRISON J., 1968. Photoperiod and pollen sterility in maize. Ann. Bot. 32: 833-846.

MURRAY B.G., HAMMET K.R., GRIGG F.D.W., 1992. Seed set and breeding system in the pepino (Solanum muricatum Aiton), Solanaceae. Sci. Hort. 49: 83-92.

PludA D., RABINOWITCH H.D., KAFKAFI U., 1993. Fruit set and yield of pepino dulce response to nitrate-nitrogen and salinity levels and thinning of side branches and trusses. J. Plant Nutr. 16: 2121-2133.

Proctor F.J., Cropley J.P., JOHNSON G.I., 1994. Trends and changes in the European market for tropical fruits and their impact on technology requirements. ACIAR Proc. 50: 65-72.

Prohens J., RUIZ J.J., NUEZ F., 1996. The pepino (Solanum muricatum, Solanaceae): A "New" crop with a history. Econ. Bot. 50 (3): 328-341.

Prohens J., RUIZ J.J., NUEZ F., 1998. The inheritance of parthenocarpy and associated traits in pepino. J. Am. Soc. Hortic. Sci. 123: 376-380. 
Redgewell R.J., TuRNer N.A., 1986. Pepino (Solanum muricatum): chemical composition of ripe fruit. J. Sci. Food Agric. 37: 1217-1222.

RUEBenAuer T., MULLER H.W., 1985. Ogólna hodowla roślin. PWN, Warszawa: 394.

RUIZ J. J., PROHENS J., NUEZ F., 1996. Efecto de la temprtatura sobre el cuajado y maduracion de frutos en pepino dulce. Acta Hort. 14: 109-118.

RYLSKI I., SPIEGELMAN M., 1982. Effects of different diurnal temperature combinations on fruit set of sweet pepper. Sci. Hort. 17: 101-106.

SAINI H.S., ASPINALl D., 1982. Abnormal sporogenesis in wheat (Triticum aestivum) induced by short periods of high temperature. Ann. Bot. 49: 835-846.

Shiota H., Young H., PeTERSON J., IRIE M., 1988. Volatile aroma constituents of pepino fruit. J. Sci. Food Agric. 43: 343-354.

\section{OCENA PŁODNOŚCI PYŁKU PEPINO (SOLANUM MURICATUM AIT.)}

Streszczenie: Badano płodność pyłku u sześciu klonów pepino o różnym pochodzeniu, w zależności od okresu uprawy roślin (wiosenno-letni i jesienny) oraz sposobu uprawy (wełna mineralna i substrat torfowy). Kwiaty do badań pobierano z trzech kolejnych gron. Płodność pyłku określano in vitro jako jego zdolność do kiełkowania. Średnia zdolność kiełkowania pyłku badanych klonów wyniosła 10-15\%. Wyższą zdolność kiełkowania pyłku u wszystkich klonów obserwowano $\mathrm{w}$ kwiatach $\mathrm{z}$ pierwszego grona z uprawy wiosenno-letniej. Pyłek $\mathrm{z}$ roślin uprawianych na wełnie mineralnej był bardziej płodny $\mathrm{w}$ porównaniu $\mathrm{z}$ roślinami $\mathrm{z}$ uprawy $\mathrm{w}$ substracie torfowym. Obserwowano duże różnice w płodności pyłku u badanych klonów. 